\title{
DEMONIC FORCES OF IGNORANCE
}

\author{
(C) Yuri A. Zhdanov
}

Yuri A. Zhdanov - doctor of chemistry, candidate of philosophical sciences, professor. Rector of the Rostov state university (1957-1988), Russian Federation.

Жданов Юрий Андреевич - доктор химических наук, кандидат фрилософрских наук, профессор. Ректор Ростовского государственного университета (1957-1988 ге.), Российская Федерация.

For with much wisdom comes much sorrow, and as knowledge grows, grief increases.

Ecclesiastes

The attention of intellectuals, philosophers and publicists, historians and essayists from all over the world have always been attracted by the inexhaustible problem of the mind and folly. Such brilliant masterpieces as Helvétius «On Mind » and «In Praise of Folly» by Erasmus of Rotterdam stand out in the vast literary literature. Russian thought is constantly returning to this topic, it is enough to recall Griboedov's "Woe from Wit", Shchedrin's "History of a City". "To the Scientist Neighbor" of Chekhov, "City of Gradov" by Platonov, in order to present the relevance of the problem.

However, one related category, in our opinion, has not attracted enough attention. This is about such a phenomenon in the sphere of consciousness as ignorance. Perhaps only Marx drew attention to this subject and expressed a mysterious sentiment: "Ignorance is a demonic power, and we fear that it will cause many more tragedies [1]. So, not the economy, not the basis, not the superstructure, not the ideology, but the simplest ignorance, the result of which can be many tragedies.

At first glance, ignorance is simply mediocrity, lack of knowledge, information, as we say now. It has long been known that a lot of knowledge does not teach the mind. Ignorance is not just ignorance; it is an aggressive self-assertion of one's own ignorance, rejecting knowledge from the doorway, being satisfied with self-containment, hostile, suspicious of knowledge, maliciously and militantly imposing itself. That is why ignorance can take a demonic character.

Ignorance is wrapped in the mantle of arrogance, it despises knowledge with complacency and swagger, and at the same time with cowardly aggression.

Ignorance is a consequence of random variations in the life of an individual: I have not studied Binomial theorem of Newton; I do not remember the distance to the Sun or the DNA formula. Ignorance is the essential characteristic of the personality. For him, experience and knowledge have not risen to a complete theoretical picture of the world. An ignorant person does not know his ignorance and therefore tries to do everything. In a letter to youth, Academician I. Pavlov taught himself to admit: "I am an ignoramus." This is the only way to overcome ignorance, to take the road of knowledge.

An ignoramus will never make this confession; for him it is self-exposure; on the contrary, he bathes in his ignorance. Pavlov paid attention to the thrill with which physiologistsagnostics denied the possibility of understanding the spiritual nature of the person. The great 
scientist noted with contempt "the delight of ignorance": I do not understand, I will not understand, I will never understand!

The origin and nature of ignorance can be very diverse. Marx severely condemned the Russian anarchists at one time for imposing on the young people a "cult of ignorance," a disrespectful attitude toward science and knowledge. This trend has not faded away and does not have only Russian passport. This is what the international journal «Nature» writes nowadays: "The high level of general scientific illiteracy in the United States and other developed countries is a potential source of erroneous policies and possible social instability" [2].

A serious source of ignorance is the arrogance of narrow professionalism, professional cretinism: if I know chemistry well, I am quite competent to talk about sociology, although I have not studied it; if the depths of mathematics are available to me, then I'm really going to deal with political problems. Norbert Wiener warned against the appearance of cybernetics who can deliver a message, but they have nothing to tell other people; hence there is dilettantism in resolving any issues that Herzen wrote about.

Denying an objective knowledge, ignorance easily merges with irrationalism, becomes a victim of charlatanism, obscurantism, fashion myths. It can profoundly argue about the "redundancy of education" in the modern world or about the need to reduce the scientific and technical base in Russia by two thirds, as in recent decisions of the Paris Organization for Economic Cooperation and Development. True, there is also complacent ignorance, when crudeness is worse than thieving.

Unable to rise to theoretical heights, ignorance seeks to transform science into an ideology, a servant of power, does not feel the intrinsic value of science as the quintessence of the universal historical development process, acting under the motto: one cannot see the forest through the trees.

Ignorance is not able to comprehend what is happening, without knowing how to understand the phenomena, the diversity of the world from their essential characteristics. Hence the capitulation of thought to the difficulties of problems. "They absolutely do not know anything and that's why they absolutely don't want to learn anything," grumbled Engels [3].

Knowledge of the essence of things requires a deep work of thought, physical strength of the mind. But, as Hegel noted, "ordinary consciousness is not at all included in the consideration of internal connections, essential in things, causes, bases, goals, but it is content to take everything that exists and make it as something separate, in accordance with its meaningless randomness [4].

The fatal role in the development of ignorance can played by the private interest of the individual or the social group to which it belongs. This interest actively impedes the knowledge and rapes the truth for self-justification. Fear of truth arises, marked by Hegel. This happened to such a serious science as political economy.

Founded by the works of the classics like William Petty, Adam Smith, David Ricardo, Karl Marx, - it suddenly degenerated into a vulgar political economy when it turned out that science is sentencing the existing system. Vulgar political economy has been reduced to a rigorous study of supply and demand, money flow, income. This is undoubtedly useful and necessary, but at the same time, unlike genuine science, vulgar political economy, Marx wrote, "declares a simple translation of ordinary phenomena into equally ordinary notions as the true work of science." While true sciences "seek to find out what is hidden behind everyday phenomena and, as a rule, in their form contradictory to everyday phenomena (such, for example, the movement of the Sun around the Earth) essence" [5].

The sad and tragic example nowadays, when the demonic force of ignorance played its tragic role, is the fate of Marxist doctrine. People do not want to understand that the current disregard for Marxist science is by its very nature very similar to persecution of MendelismMorphism in biology or persecution of cybernetics. But this process has deep roots. 
At the time, a wonderful Russian thinker and revolutionist G.V. Plekhanov, once in emigration, was surprised to note: "I begin to think that Marxists are very rare birds in the socialist parties of the West" [6]. He sadly summarizes: "There are professors, "people of science", who in their works have erected for themselves an indestructible monument of absolute inability to grasp the meaning of Marx's teachings" [vol. 3. p. 49]. Alas, there were a lot of such professors and academicians, and not only in the West.

It should be noted that Lenin shared the position of his comrade-in-arms and at the same time rival Plekhanov. Making notes and discussing the works of Hegel in his «Philosophical Notebooks», Lenin came to an unexpected conclusion: "You cannot fully understand Marx's "Capital" and especially its first part, without having studied and understood Hegel's entire Logic. Consequently, none of the Marxists understood Marx half a century later! " [7]. How many people understood later?

In order to understand Marxism, it is necessary not just to see the top of an iceberg, but to understand also its roots, origin and constituent parts. Marxism is dead; if not to see its historical roots, it degenerates into an ideology. To understand, to discover Marxism, you need to know the entire history of philosophy from the Eleatic philosophers like Aristotle, Plato, Spinoza, Descartes to Kant and Hegel. It is necessary to understand the movement of economic thought from Ibn Khaldun, Smith, and Ricardo to Marx. The history of sociological, political, religious thought from Herodotus, Thucydides, Augustine, Luther, Campanella, Thomas More, Saint-Simon Comte, Spencer to the present times cannot be avoided.

Marxism absorbed all the wealth of global culture - Homer, Cervantes, Shakespeare, Pushkin, Rembrandt, Beethoven, Balzac and Goethe. Now we need to add to this all the subsequent development to Einstein's theory of relativity, Gibbs' thermodynamics, quantum mechanics, Hacken's synergy, Hubble's astrophysics, as well as Darwinism and genetics, the theory of catastrophes and the views of Prigogine.

But the widespread use of Marxism could not but lead to belittling its theoretical level. The bureaucracy, the native child of capitalism, could not help but condemn it to ossification and dogmatization. Nevertheless, we should remember the words of quite independent thinkers of our time.

Here is what Vernadsky wrote: "The concept of the noosphere, which derives from biogeochemical concepts, is in complete harmony with the basic idea, penetrating "scientific socialism" [8]. Einstein in his work "Why socialism?" holds the same view.

The former European and then American philosopher and psychologist Erich Fromm in his book "The heart of man" describes the current situation with Marxism in this way: "The irony of history is that, despite the availability of sources, in the modern world there is no limit for distortion and misinterpretation of various theories. The most striking example of this kind is what has been done in the last decade with the teachings of Karl Marx" [9]. Ignorance, mercenary social and class interests joined forces to destroy Marxism. However, one cannot but agree with the prominent American economist and sociologist J. Galbraith: «Commitment to Marx ... continues to remain a sign of courageous thinking» [1].

Not only the selfish interests of "adult uncles" give rise to ignorance. There is another very serious, very deep, one might say, cosmic cause. Yes, in the past there were Aristotle and Darwin, Einstein and Marx, Pushkin and Tolstoy. But every time a small living miracle is born from the great non-existence of the Universe, which does not know anything about it, whose genes of mother and father did not transfer to the traditions of culture, which everyone has to learn in a short moment of being. Will it succeed? Will not many pass by the wealth of culture, science, moral and artistic achievements of humanity, historical experience? The problem of discontinuity and continuity of generations is one of the most essential for the destinies of humankind. Ignorance parasites on it, seducing young souls with marsh lights, bright decoys. Therefore, the problem of shaping the culture of the new generation, education, and initiation of the entire wealth of knowledge and skills is a key. 
An individual entering the world must go through the thorny path of communion with the patrimonial essence of the person, which is possible only through culture in its universal meaning as a unity of labor, cognitive, artistic, aesthetic, value-oriented activities in the field of communication. If the fate of the individual is played by the dominant, decisive role of alienated forms of human relations, traditions of antagonisms, aggressiveness and elements of destructive violent actions, then it is not associated with culture, but with anticulture, which is identical to triumphant of ignorance. In fact, it is not Homo sapiens that forms this basis, but more or less "intelligent beast", using Plekhanov's expression. The technical achievements of our time open up unprecedented opportunities for him to celebrate the demonic force of destruction, aggression, violence, terror. However, ignorance is only a possible prerequisite for ignorance. The latter is not transmitted with genes, including the distant heritage of animal ancestors. Erich Fromm paid attention to this circumstance in his work on the problem of human destructiveness. According to his concept, destructiveness is born by a system of social relations, primarily alienation: "A man of the technical age suffers not so much from a passion for destruction, but from total alienation" [11]. The new type of alienation was born primarily by the "market man", focused on the system of property relations, property values, which is most clearly manifested in the American ruling class. "He turns his interest away from life, from people, from nature and from an idea - in short, from everything that lives: he turns all life into objects, things, including himself and his human qualities: feelings and intelligence, the ability to see, hear and understand, feel and love [11. p. 301].

On social and psychological levels, we are talking about those who have not received recognition and have not found their place in the social structure.

Fromm did not include the category of ignorance in the system of destructiveness, but this follows from the course of his reasoning. It is not a coincidence that he speaks of aggressive irrationalism.

Maybe, ignorance is a necessary element of development, overcoming the frozen, ossified, old and traditional? Hardly so. Rather, here we should talk about empty negation, but not about dialectics, for which negation means a moment not only to overcome the past, but also to retain it while preserving the positive content of previous development.

The problem of ignorance should be considered in the cultural aspect, namely in the context of anticulture, which is not confined to the metaphorically vague definition of something bad, but is understood as a false foundation of being. If culture is the way of selfrealization, formation, is revealed to the human essence, then anticulture is the way of its degradation, destruction, demolition.

Describing culture as a way of activity, synthesizing creative productive-transforming, cognitive, artistic and aesthetic, value-oriented forms of activity, the way people communicate with other people and nature, we see the focus of polar opposite qualities in anticulture. Not the imaginative creation of the objective world, but the production and use of means of destruction, not the knowledge of the laws of nature and society, but the irrational-mystical antiscience; not the formation of the world according to the laws of beauty, but the triumph of the ugly aesthetics: not morality, but the baseness of cynicism, servility and defection; not cooperation and mutual assistance of people, but exploitation and domination-submission; not the coevolution of nature and society, but the transformation of the environment into a cesspool. At the same time, ignorance is the ideology of this anticulture, as a result of the total alienation of man from his essence.

It would be naive to seek salvation from total alienation in its particular forms, trusting either to the market and money or to religion, to scientism, or to sectarian retreat or even to perfectly soulful humanistic values. And not of the genetic heritage of biological ancestors, a wombat or a cheetah, it is necessary to get rid, but of acquired antagonisms born by private ownership of tools and means of production, by the whole world of alienation. 
Ignorance will not disappear on the basis of educational activities only. In the society of his premise must be overcome; the alienated nature of being, the destructiveness of social relations, the immanent devastating nature of social antagonisms that give rise to total violence, war, mass terror, not only at the level of states, but also domestic relations.

We are accustomed to consider the mind as a generic attribute of a person. But in order to become rational, you need persistent, permanent work of each individual, aimed at mastering the history and culture of thinking. The real, empirical fact is that most people do not pass such a school. In fact, they are alienated from the achievements of the rational spirit. The famous French mathematician Henri Poincaré discussed this sad story: "But most people do not like to think, and maybe this is for the better, because they are guided by instinct, and it usually guides better than intellectual considerations, at least in all cases when people mean the same immediate goal. However, instinct is a routine, and if thought did not fertilize it, it would not have progressed more in a human being than in a bee or an ant. It is necessary, therefore, that someone think for those who do not like to think" [12]. This, of course, is good if at least someone thinks; others are left to be comforted by the «sigh» of the evangelists: forgive them for they do not know what they are doing.

Such ignorance may not be very dangerous if it relates to a narrow circle of household troubles, momentary fuss. However, it takes on formidable forms when it comes to human lives, problems of historical development, and future generations. The lack of a scientific approach, deep analysis at the level has led to dramatic consequences. F. Engels once warned about this danger: "This transformation into its opposite, this achievement of such a point, which is diametrically opposite to the original, constitutes the naturally inevitable fate of historical movements, whose participants have a vague idea of the causes and conditions of their existence and therefore put before them purely illusory goals "[13].

No one is surprised that telescopes and spectroscopes, satellites and rockets are needed for the knowledge of Space; that cyclotrons, synchrophasotrons, and computers are needed to understand the atom. However, for some reason it is believed that for the knowledge of society, the management of social processes, special efforts are not required, it seems that everything is clear to everyone. In fact, to know human society is many times more complicated and difficult. And a tool of knowledge created by a long history is the only one: the dialectical method. Moreover, all are obliged to seize it. Otherwise - the endless cramps of the social organism.

Everyone is called upon to contribute to overcoming the deadlock in the development of mankind, mobilizing their historical experience and reason. For people of science in this regard, it would be useful to return to the idea of Vernadsky, who proposed "non-state organized forms of the world scientific environment" - because "the idea of the "scientific think tank» of humanity was put forward by life" [14]. This could help to unite science and democracy, knowledge and creative power of labor, search for ways to overcome all forms of alienation, including the demonic force of ignorance.

\section{Лumepamypa}

1. Маркс К., Энгельс Ф. Соч. Т. 1. С. 112

2.Ziman J. Monthly Nature. Febr. 1994. Vol. 2. № 2. P. 37.

3. Маркс К., Энгельс Ф. Соч. Т. 36. С. 77.

4.Гегель. Эстетика. Т. 3. М., 1971. С. 358.

5. Маркс К., Энгельс Ф. Соч. Т. 4. С. 612.

6. Философрско-литературное наследие Г.В. Плеханова. М., 1973. Т. 2. С. 158.

7. Ленин В.И. Полн. собр. соч. Т. 29. С. 162.

8. Вернадский В.И. Размышление натуралиста. Кн. 2. М., 1977. С. 67. 
9. Фромм Э. Душа человека. М., 1992. С. 376.

10.Гэлбрейт Дж. Экономические теории и цели общества. М., 1976. С.163.

11. Фромм Э. Анатомия человеческой деструктивности. М., 1994. С. 229.

12. Пуанкаре А. О науке. М., 1990. С. 373.

13. Маркс К., Энгельс Ф. Соч. Т. 22. С. 21-22.

14. Вернадский В.И. Размышление натуралиста. М. 1977. Кн. 2. С. 68- 69.

\section{References}

1. Marks K., Engels F. Soch. [Essays]. V. 1. 112 p. (in Russian).

2. Ziman J. Monthly Nature. Febr. 1994. V. 2. No. 2. 37 p.

3. Marks K., Engels F. Soch. [Essays]. V. 36. 77 p. (in Russian).

4. Gegel. Estetika. V. 3. Moscow, 1971. 358 p. (in Russian).

5. Marks K., Engels F. Soch. [Essays]. V. 4. 612 p. (in Russian).

6. Filosofsko-literaturnoe nasledie G.V. Plehanova [Philosophical and literary heritage G.V. Plekhanov]. Moscow, 1973. V. 2. 158 p. (in Russian).

7. Lenin V.I. Poln. sobr. soch. [Complete works]. V. 29. 162 p. (in Russian).

8. Vernadskiy V.I. Razmyishlenie naturalista [Naturalist Reflection]. B. 2. Moscow, 1977. 67 p. (in Russian).

9. Fromm E. Dusha cheloveka [Human soul]. Moscow, 1992. 376 p. (in Russian).

10. Gelbreyt Dzh. Ekonomicheskie teorii i tseli obschestva [Economic theories and goals of society]. Moscow, 1976. 163 p. (in Russian).

11. Fromm E. Anatomiya chelovecheskoy destruktivnosti [Anatomy of human destructiveness]. Moscow, 1994. 229 p. (in Russian).

12. Puankare A. O nauke [About science]. Moscow, 1990. 373 p. (in Russian).

13. Marks K., Engels F. Soch. [Essays]. V. 22. pp. 21-22 (in Russian).

14. Vernadskiy V.I. Razmyishlenie naturalista [Naturalist Reflection]. Moscow, 1977. B. 2. pp. 68- 69 (in Russian).

Опубликовано на русском языке в книге: Ю.А. Жданов. Избранное. Ростов-на-Дону: изд-во СКНЦ ВШ ЮФУ, 2009. В 3 т. T. 2. с. 52-61.

На английском языке публикуется впервые.

The article is published in Russian in the book: Y.A. Zhdanov. Selected writings. Rostov-on-Don. Publish house NCSC HS SFU, 2009. In III volumes. V. II, pp. 52-61.

In English it is published for the first time. 